\title{
AESTHETIC MEANS OF ETHICAL ENGAGEMENT IN RITHY PANH'S THE MISSING PICTURE
}

Keywords: trauma; aesthetics; ethics; genocide; Khmer Rouge; documentary film. Abstract: In the context of the sensorial fatigue caused by the media's saturation with representations of violence, Rithy Panh's film The Missing Picture (2013) stands as a reinvigorating alternative of addressing trauma through aesthetic means that inscribe the affect within ethical dimensions. Panh's testimony of surviving the death of his family through Pot Pol's 'killing fields' is built around images of stylized clay figurines filmed in realistic dioramas. Forced labor, starvation and death make living a luxury - life fades away from the bodies of figurines that lose color and flesh, but is reaffirmed through the lush nature of dioramas and the resiliently colorful presence of the hero, the surviving storyteller. Khmer Rouge archival footage of carefully choreographed masses of people works as abstract imagery of an unreal reality. In an unmediated expression of affect, the sound mixes revolutionary choirs with electronic effects registering a fading daily life, and voice-over commentary that recuperates the words of propaganda slogans and shapes them into a personal narrative of wonder, pain, anger and guilt of survival. Panh achieves here " $a$ formulation of affect understood as a radical act of interpretation in the face of unwilled subjugation", in Judith Butler's words on the poems of the Guantanamo detainees. (Butler 61) By mobilizing the realm of the affects through aesthetics, Panh fulfills what Simon O'Sullivan calls "the ethical imperative of art [that] involves a kind of moving beyond the already familiar (the human), precisely a kind of selfovercoming”. (O’Sullivan 129) Rithy Panh's The Missing Picture works as an art organism that leads us to recover our subjectivity through the detour of a necessary perception of our objectivity. It allows us access to the position of subjects concerned about the others only through the mediation of our occupying the position of objects perceptible as others.

In the context of the sensorial fatigue caused by the media's saturation with representations of violence, Rithy Panh's film The Missing Picture (2013) stands as a reinvigorating alternative of addressing trauma through aesthetic means that inscribe the affect within ethical dimensions. The Missing Picture is the expression of Rithy Panh's search for a form of representation of the un-speakable, the un-nameable, the un-thinkable. The film comes as the author's attempt at rendering visible a momentary nightmare that arrested his childhood and lasted for four years - a gesture similar to a desperate reach at grasping impressions lived during a state of clinical death. The film speaks from inside a tragedy, through a first person account lyrically sublimated

\footnotetext{
${ }^{*}$ University of California, Berkeley; USA.
} 
within the voiceover commentary. After twenty-four years of cinematically surrounding the context of the Cambodian genocide, Rithy Panh gathered the strength to touch the burning center of his trauma - his personal experience as a child witnessing and surviving the loss of his family in the 'killing fields'. In his previous films, he approached victims and perpetrators, and asked for their testimonies in an effort to understand the enormity of four years of history that, although proven to be the time of the killing of close to two million people, have been rendered ephemeral and of the past by the Cambodian government who tried to implement a politics of 'forgetting and forgiving'. Rithy Panh's cinematic engagement thus holds a double urgency - that of a personal attempt at coming to terms with "a past he would have wished to forget” (Burnet 39), but also of a process of collective memory restitution, and moral reparation aimed at a people in danger of forgetting its recent past.

The testimonies of the people interviewed in Rithy Panh's previous films serve as individual accounts of a collective truth, like pieces in a horror story puzzle. While establishing an ethical ground for the victim-perpetrator encounter, Bophana: A Cambodian Tragedy (1996), S21: The Khmer Rouge Killing Machine (2003), and Duch, Master of the Forges of Hell (2012) bring into the focus of social and political debates issues of individual versus collective responsibility, acknowledgment of criminal facts and behavior versus falsification and denial, and assumed agency versus pretence submissiveness. Panh's intention is not to assemble evidence in support of a direct indictment, but rather to unearth the past and restore the memory by bringing his subjects to name their deeds and describe their implication in the process of killing. By allowing the context for his films' social actors to acknowledge their position of conscious subjects in a nation's tragedy, Panh traces the only responsible way towards the healing of an open wound, both personal and collective.

The Missing Picture is an essay film built around the role of representation in relation to truth, a truth at once collective and individual, 'objective' and 'subjective'. The film posits truth as an ideal construct that escapes representation - on the one hand, Rithy Panh sets out to build an illusory image for his subjective 'truth'. On the other, the Khmer Rouge footage of the joyfully working termite-people hints to a subjective 'truth' different from the one officially imposed. This truth that elides expression relates to the experience of trauma, and Rithy Panh engages on virtually the most difficult step of his filmic projects - the retelling of collective trauma as lived by himself. He knows all too well the risks assumed by the witness who takes on the role of the storyteller, as his film beautifully evokes - the boy who recounts the Apollo 11 lunar landing as a bedtime story in the forced labor camp, and the Khmer Rouge cameraman whose recording captures less than perfect images of the 'leap forward' reality of Democratic Kampuchea disappear both as 'reduced to dust'. Their disappearance stands in for the Khmer Rouge's sequestration and reappropriation of both words and images as means of representation. In spite of this, or rather because of it, the telling of his story becomes for Panh both a moral duty and a psychological necessity, a recuperatory act that starts at the level of the words: written in 2012 collaboration with novelist Christophe Bataille, The Elimination is a book that integrates the account of Panh's interviewing of Kang Kek Lev, the Khmer Rouge leader known as Duch, within the narrative of the author's living through the Khmer Rouge's seizing of power, the displacement of population to the forced labor camps, 
Trauma, Narrative, Responsibility

and the loss of his whole family. A follow up of the words at the level of images, the film The Missing Picture announces an engagement with the act of remediating the absence of visual representation. The film takes on the autobiographic elements of the book, and uniquely reflects on a traumatic personal truth by bringing up an element absent from Panh's earliest films - an evocative account of an agonizing selfperception of the victim as being guilty for surviving. The film comes after the author - the victim - has approached the perpetrators with his own weapon, the camera, and has forged their answer to the 'how?' question. Self-reflectively now he turns the question on himself: how is that he survived, and how, while being there, he failed to help the others, his family, survive. Through his film, Rithy Pahn models an answer that he never obtained from his previous subjects as he reflects on the effects of ideology on people's belief in the Revolution, and on the monstrous transformations suffered by the individuals' human qualities. The Missing Picture succeeds exactly because it recognizes its failure, or the mere impossibility of succeeding: the film resonates profoundly throughout our affective self as it remains the expression of a longing, of a process of convergence to its limit, to reaching that image, that picture that remains missing.

In his book The Essay Film, Timothy Corrigan writes: "In the most demanding essays and essay films, [there exists] this interactive confrontation [that] destabilizes not only the authorial subject but also the resulting text and the reader/viewer's apprehension of it.” (Corrigan 20) This article will attempt to identify and unpack these techniques of 'destabilization' at work in The Missing Picture. Rithy Panh was constrained to reassess his authorial stance from the moment he started thinking about this film, as the journey of its production proved to be treacherous and filled with detours and obstacles. In an interview with Nick Bradshaw from the BFI, the filmmaker recalls how he stopped shooting and changed everything when, after a year and a half worth of work, he came to the idea of using clay figurines:

But I'm lucky because the producers liked the results. It's not easy to make a film with clay figurines for an hour and a half, to keep attention, give emotion, maintain a cinematographic point of view. Imagine going to see [funders] and tell them: 'I want to make a film about my childhood, and I'll use clay figurines.' Everybody will go away. Talking like that will not work. (Panh, "Memories of Murder")

The discourse of the film questions the process of its own making. While this is visible at different occasions, it remains most memorable at the moment of the imagined dialogue between Panh's parents when seeing their son interviewed on TV5 about his latest film on the genocide (probably Duch). The recourse to reflexivity is inflected by a psychoanalytical need to redeem his self-perceived guilt, while clearing the ground for a long due process of mourning. At the level of the film as text, the destabilization defined by Corrigan is manifest in the apparent disproportion or inadequacy between the theme of the film (with its implied tragic dimensions) and the form of expression (the clay figurines). This is the first time that the director, previously known to address this subject within a realistic, participatory style, proposes a virtually minimalist and stylized approach. The extent to which the film form may prove to be a challenge for the audience's reception can be anticipated by 
the extent to which the film posters with images of clay figurines are able to attract or keep at a distance potential viewers. The viewer who does decide to go into the theater will witness the process of the making of figurines as a sensory ritual meant to give body and soul to the disappeared. The visuals and music build a spectacle of an austere and terrifying beauty. This is possible as they function in relation to the French-spoken lyrically evocative and factually poignant commentary that operates on the viewer by opening a wound and then tending to it just enough so it would never heal. The viewer is pulled in different sensorial and affective directions, and the resulting tension is akin to the destabilization that Corrigan considers necessary for a successful essay film.

In his psychoanalytic work with trauma, Dori Laub describes trauma as "outside the range of comprehension, of recounting and of mastery", as "an event that could not and did not proceed through to its completion”. (Laub 69) He thus proposes:

To undo this entrapment in a fate that cannot be known, cannot be told, but can only be repeated, a therapeutic process - a process of constructing a narrative, of reconstructing a history and essentially, of re-externalizing the event - has to be set in motion. This re-externalization of the event can occur and take effect only when one can articulate and transmit the story, literally transfer it to another outside oneself and then take it back again, inside. Telling thus entails a reassertion of the hegemony of reality and a re-externalization of the evil that affected and contaminated the trauma victim. (Laub 69)

By the time of the writing of his book The Elimination, Rithy Panh acknowledges: "The evil done to me is inside me. Lying in wait. Many years, many encounters, many tears, and much reading will be necessary for me to overcome it." (Panh and Bataille 6) For him, the process of constructing his narrative takes years of searching for images for his memories, images assembled within films that focus on people affected by, or involved in the tragedy. He writes: "My documentaries Bophana and S21 were shown in Cambodia. Like me, the country was able to retrace its memory. I felt that those films had brought an episode in my life to a close.” (Panh and Bataille 13) While working on Bophana, the filmmaker encounters Van Nath, a painter and former prisoner of S21 whose paintings, representing different types of torture used at S21, are part of the museum that is now on the site of the prison. Rithy Panh recalls his reaction when, during his interviewing of Duch, this one criticized the quality of Nath's painting: "I reply that Nath's work deals powerfully with memory, and that's what one must analyze. Nath is a painter and a survivor - and a survivor because he was a painter." (Panh and Bataille 108) This last observation attests to the reality of Duch requesting Nath to paint portraits of Pol Pot (from photographs and propaganda films) during one year while in Toul Sleng (or S21). But looking at the painter's subsequent work that focuses on the reality of the extermination center, we can read Nath's survival because being a painter as a conduit of healing akin to Dori Laub's process of finding an expression for the trauma's narrative. Through his own means, Van Nath is doing a work parallel to that of Rithy Panh - that of an expressive re-externalization of the evil through images. As for himself, the filmmaker will write: 
"I chose film, which shows the world, presents beauty, and also deals in words. I figure it keeps my fists in my pockets." (Panh and Bataille 7)

Concomitant with the beginning of Duch's trial, Panh started interviewing him for his film, in the conviction the "the images will tell the story". (Panh and Bataille 13) This process would prove to be an ordeal for the artist, as the perpetrator refuses to fully acknowledge the truth of his horrific participation, and thus misses what Panh envisioned as the crime-ideologist's chance at recuperating his human condition. Panh's meditation on the significance of these conversations drew him closer to his own memories of tumultuous survival through the four years of the Khmer Rouge takeover. Written in French in collaboration with writer Christophe Bataille, the book The Elimination weaves in Panh's analytical deconstruction of his disturbing encounter with Duch's, with the sensorial and affective first-person recollection of the writer's survival and loss. While Dutch evasively escapes scrutiny inside a deformed language that operates in Khmer Rouge slogans, and invokes ideology as justification for the elimination of a whole people of 'enemies', Panh takes a step back to write down his thoughts on the man's attitude, character, forms of expression, and performance of heroic identity. In the process, he observes, and makes notes of his own visceral reliving of the past through old sensations preserved by the memory of the body. The book comes into being as the filmmaker/writer's need to gain a critical perspective over the overwhelming memories triggered by the traumatic encounter. The Elimination functions thus as an achievement of Panh's sustained effort towards healing.

The book stands also an attempt to recuperate the truth of the language lost in the stiffness of slogans, and to channel it into words able to return an aesthetic dimension to the truth of the lived story. There is still ample theoretical debate regarding the legitimacy of bringing the aesthetic - understood as the quality of art that enables a sensorial experiencing of it - in relation to representations, especially visual, of extreme violence, or traumatic experience. Rithy Panh's use of words allow a distance that invites our sensorial engagement as distilled within our critical stand, allowing for both aesthetic and ethic contemplation. Towards the end of the book, he writes:

I reread these pages. I'd like to erase my childhood. And leave nothing behind: not the words, not the pages, not the trembling hand holding them; not the warm paving stones in the entryway where my mother waited; not the spirals; not the dizzy spells. There would be nothing left except Duch and me: the story of a combat. I've filmed his oversights and his lies. His hand, wandering over the photographs. His forceful, sudden respiration, as if the exaltation of former days were still there, in his lungs. (Panh and Bataille 200)

These words attest that, while surviving the past, Rithy Panh is entrapped in his memory of it, from which he can escape only by attaching it to the collective, public memory. Within a condensed, sublimated expression, the words affirm the necessity of a critical reassessment of the past for the writer's ability to live in the 
Trauma, Narrative, Responsibility

present. Borrowing Judith Buttler's notes about the poems written by Guantanamo prisoners, it can be said that The Elimination allows Rithy Panh the appropriation of words as "a formulation of affect understood as a radical act of interpretation in the face of unwilled subjugation”. (Butler 61)

While fully aware of the power of words on our imaginary, Rithy Panh is foremost a filmmaker in search of ways of expressing memories of a "genocide without images". (Panh and Bataille 249) The Cambodian tragedy has become associated with the series of photographs of prisoners that were about to be tortured and killed at Tuol Sleng (S21), taken and archived by the Khmer Rouge photographers. Misappropriated by art galleries, and exposed with no context throughout Western museums, these mug shots have become the subject of remote contemplation, as Susan Sontag writes:

These Cambodian women and men of all ages, including many children, photographed from a few feet away, usually in half figure, are . . . forever looking at death, forever about to be murdered, forever wronged. And the viewer is in the same position as the lackey behind the camera; the experience is sickening. The prison's photographer's name is known - Nhem Ein - and can be cited. Those he photographed, with their stunned faces, their emaciated torsos, the number tags pinned to the top of their shirts, remain an aggregate: anonymous victims. (Sontag 60)

In her article addressing some of the ethical and aesthetical implications of this practice, Stéphanie Benzaquen identifies artists that dedicate their work to "regaining another form of bearing witness, and deconstructing the perpetrators' aesthetics and ideology, which still impregnate these images - in other words: restoring the victims' humanity”. (Benzaquen 210) Rithy Panh’s The Missing Picture stems from a similar attempt at creating images able to express a subjective experience preserved by memory, without romanticizing the victim or allowing the perpetrator the power of his gaze. For the filmmaker, the project becomes more personal as it involves the remediation of a painful absence - that of the images of his familial past and childhood abruptly interrupted.

The austere, stringent and reflexive lyricism of the autobiographical text from The Elimination is condensed into the narration of The Missing Picture, and amplified through the reverberating effect of the haptic images and harrowing sound. The visual and aural registers at work in creating this expressive experience are constituted by the images of clay figurines framed through camera moving around colorful dioramas, the archival black and white footage of Khmer Rouge propaganda films (with two exceptions that are in color), the black and white newsreel footage, the inserts of color moving-images giving details of real-life, the commentary written by Christophe Bataille and narrated in French by Randal Douc, and the complex treatment of sound that fuels the simmering audio-visual tensions. Panh recalls how, when asking Sarith Mang, his assistant at the Bophana Audiovisual Center, to make a model of his childhood house and a boy figurine to live in it, he realized his assistant's real talent at sculpting in clay, and decided that he will use clay figurines to tell his story. (Hart, 
“The Power of Constraint”) For Panh, this meant the chance of a symbolical restoration of the embodied materiality his people have been denied. He writes:

Nothing belonged to me, not even my nakedness. Or, if I may say so, not even our nakedness, for I don't remember ever seeing a bare, living body. . . . Only an individual has a body. Only an individual can look out from inside his body, which he can hide, offer, share, wound, bring to orgasm. Control of bodies, control of minds: the program was clear. (Panh and Bataille 187)

Towards the end of the film, Panh's longing is expressed through the narrator's voice: "I seek no pictures of loved ones, but rather to touch them.” Indeed, the film starts with the hands of Sarith Mang skillfully crafting and painting a little clay figurine, and the following words spoken in a supple, distilled French: "Avec de la terre et du l'eau, avec les morts et le rizières, avec des mains vivants, on fait un home. Il suffit de pas grand chose, il suffit de vouloir. Son costume est blanc, la cravate sombre. Je voudrais le tenir contre moi. C’est mon père.” ${ }^{1}$ Through these words, Panh references a double undoing - at the level of language, this description of a demiurgic making of man undoes the Khmer Rouge's devising of the word kamtech - to destroy and then to erase all trace, to reduce to dust. (Panh and Bataille 103) At the level of the act itself, the words announce the project of the film - to undo the erasure of traces, to reverse the reducing to dust into a making back out of earth, to affirm the resilience of life by celebrating its memory.

The clay figurines are not designed as formally beautiful objects meant for our aesthetic contemplation. The sculptor molds its material to show both individual deterioration and collective stagnation. The dolls are abstract, stylized representations of people's contingent existence. The tableaux vivants of city dwellers that nostalgically revisit the memory of the storyteller show colorfully dressed chubby people, gathered in groups to talk, play, sing, make movies, eat, and generally interact. The camera pans sinuously between them, mimicking human vision through the selective focus that pauses on details of gestures, postures or attitudes made visible throughout blurred surrounding objects. The sound here mixes background voices of merrily chatting people with close-ups of songs that slightly deviate suggesting a soon-to-be-lost carefree loisir. Indeed, throughout the film, the sound is the one to foreshadow the impending doom. Rithy Panh's longtime collaborator Marc Marder declared that, for him, the sound stands in as the soul of the people embodied by the clay figurines. The musician combined and electronically manipulated different sounds alongside Khmer Rouge rally songs, such that they would become unrecognizable, and, in Panh's words, "so that the audience would experience the pain it evokes in him”. (Dowell, "Cambodia's 'Missing Pictures””)

Subtly shifting between tones that are meditative, menacing, eerily abstract, plaintive, or ironically referential, the sound operates at the level of the affect. It makes the viewer sensible to the fluidity of the subjective perception of an experience characterized in the end, on the contrary, by fixity and non-evolution. The contrast

\footnotetext{
${ }^{1}$ With clay and water, with the dead, with rice fields, with living hands, a man is made. It doesn't take much, it just takes will. His suit is white, his tie is dark. I want to hold him close. He is my father.
} 
between a sense of process or transformation inherently associated with the living, and the system's closed future frozen in the vision of the perfect - and perfectly inhuman - society, is beautifully made apparent in the treatment of the visuals. Doubly articulated, the suggestion of life goes in opposite directions. Once enrolled in the revolutionary ranks, the figurines lose their color and fleshiness, their bodies start bending and melting with bones and ribs showing though ragged black clothes, their faces become crossed and wrinkled. The gradual deterioration stands in as a sign for the presence of life in these otherwise still bodies, as a perceptible aliveness that slowly fades away. The only one who keeps his colored shirt is the young boy who survives to tell the story - the painting of his pink polka-dots shirt is so narrated: "To hang on you must hide within yourself a strength, a memory, an idea that no one can take from you. For if a picture can be stolen, a thought cannot.” In the opposite direction, the dioramas recreate the image of the nature pulsating with life - through lush green vegetation of jungle or rice fields, buffalos gathered around the thirsty boy, or live fish in the made-up muddy pond - as a parallel universe where life continues outside the reach of the walking-dead figurines.

While the dolls remain still, the camera slowly pans and tilts, dollies and cranes in long takes that create the illusion of movement - a slow, dragging movement through pain, hunger, illness and fear as made palpable through the presence of words and sound. The stillness becomes slowness, and gives expression to the lack of perspective and future, to the deadly illusion of the ideological project. For Rithy Panh, the slowness is also a marker of truth in an undoing of the Khmer Rouge propaganda images that project at distorted speed lines of people running across labor sites with sand pails hanging on shoulder poles. Panh salutes the memory of Khmer Rouge cameraman Ang Sarun that stood out through his "slow and true" images that retained the hidden, dreadful reality. His footage survived his being reduced to dust.

Ten minutes into the film, Panh achieves a striking avant-garde effect through the combination of archival footage, commentary and music. In a geometrical, black and white choreography, we see birds-eye view pannings of vividly marching people, like a moving rendition of a Pieter Brueghel's painting. Our visual contemplation is perturbed and disoriented by distorted fragments of revolutionary choirs that occupy the aural background while accommodating the commentary, or by eerie electronic treatments that take the full stage of our hearing. The narrated words bring in the authorial voice that deconstructs the slogan into reporting of reality, suggestion of incrimination, and retrospective announcement of a future now belonging to the past:

Angkar cares for you all, comrades, brothers and sisters, fathers and mothers. The Angkar is the organization, it is all, it is each. The young Khmer Rouge, the village chief, the torture supervisor, and Pol Pot. They survey this barefoot people of sand and dust. Soon there will be no more faces, no more friends, no more love, no more father and mother. Soon there will be no more emotion and even words will be transformed. Each being will be a revolutionary or fertilizer for rice.

While the dissonant music exposes the gap between the formal effect of the image and the deceiving means that went into its construction, the commentary performs a similar exposure at the level of language - the seductive, formal perfection 
Trauma, Narrative, Responsibility

of the slogan proves to be a façade meant to cover the emptiness of an ideology that annihilates the society it claims to build. This sequence illustrates the ways in which The Missing Picture penetrates and overwhelms our senses in order to provoke a response as informed by an ethical stand.

Rithy Panh's use of the camera forces us to stop and acknowledge the matter the world is made of. We are summoned to ponder texture, color, light, and movement as we would experience them for the first time. The music reframes our visual perception as it relays the aesthetic involvement to the affects. Referring to the effect of the art on the realm of the affects, Simon O'Sullivan writes:

At stake in art is not an utopian and, in some senses, negative aesthetic, but an

affirmative actualization of the virtual - the latter being a genuinely creative act (as opposed to the realization of the possible, which ultimately always already resembles the real). The virtual here can be understood as the realm of the affects. Art precisely actualizes these invisible universes; or at least it opens up a portal onto these other, virtual worlds. ... This gives art an ethical imperative, because it involves a kind of moving beyond the already familiar (the human), precisely a kind of self-overcoming.

(O’Sullivan 129)

This 'ethical imperative' is reaffirmed in the film by the voice of the commentary. The words perform the bridging between one's awareness of the world as being both for and of the matter - the perception of objects for what they are, but also the experience of them in what they are - and the positioning of the individual as subject defined by the assuming of an ethical stance. In her text "The Passion of the Material", Vivian Sobchack places our own "reversibility as subjects and objects" (Sobchack 288) as condition and premise for "a single system of reversible valuation that does not bifurcate ethics and aesthetics as they emerge from and in our material existence”. (Sobchack 295) In one's awareness of oneself as an objective subject, "the body-subject experiences ... its sensual and sensible expansion, and an enhanced awareness of what it is to be material". This "provides the material foundation of our aesthetic behavior toward the world and others", our "material sense-ability". (Sobchack 290) At the same time, the awareness of oneself as a subjective object allows us "the possibility of recognizing - and caring for - material objects external to ourselves, ... thus intimately engages us with our primordial, prereflective, and passive material response-ability," or "that particular ethical concept we call responsibility". (Sobchack 288)

Rithy Panh's The Missing Picture addresses simultaneously our sense-ability and response-ability. The film works as an art organism that leads us to recover our subjectivity through the detour of a necessary perception of our objectivity. It allows us access to the position of subjects concerned about the others only through the mediation of our occupying the position of objects perceptible as others.

\section{Works Cited:}

Benzaquen, Stéphanie. "Remediating Genocidal Images into Artworks." Oppenheimer and Ten Brink, 206-223. 
Trauma, Narrative, Responsibility

Burnet, James. "Rithy Panh, parcours.” Text that accompany the DVD Le Cinéma de Rithy Panh, Éditions Montparnasse. Print.

Butler, Judith. Frames of War. London: Verso, 2010. Print.

Corrigan,Timothy. The Essay Film. Oxford: Oxford University Press, 2011. Print.

Dowell, Pat. “Cambodia’s 'Missing Pictures' Molded from Director's Own Life.” NPR, Weekend Edition Sunday, March 30 2014,

www.npr.org/2014/03/30/295811954/cambodias-missingpictures-molded-fromdirectors-own-life. Accessed May 102014.

Felman, Shoshana and Dori Laub. Testimony. Crises of Witnessing in Literature, Psychoanalysis and History. New York: Routledge, 1992. Print.

Guerin, Frances and Roger Hallas, ed. The Image and the Witness. London: Wallflower Press, 2007. Print.

Hart, Hugh. “The Power of Constraint.” Fastcompany, March 20 2014,

www.fastcocreate.com/3027819/the-power-of-constraints-how-missing-pictureused-clay-figures-to-reenact-cambodias-nightmar. Accessed May 52014.

Laub, Dori. "Bearing Witness.” Felman and Laub, 57-74.

Oppenheimer, Joshua and Joram Ten Brink, editors. Killer Images. London: Wallflower Press, 2010. Print.

Oppenheimer, Joshua. "Perpetrators' Testimony and the Restoration of Humanity." Oppenheimer and Ten Brink, 243-55.

Panh, Rithy and Christophe Bataille. The Elimination. Éditions Grasset \& Fasquelle, 2012. Translation by John Cullen. New York: Other Press, 2012. Print.

Bradshaw, Nick. "Memories of murder: Rithy Panh on The Missing Picture.” BFI, January 7 2014, updated February 102019.

www.bfi.org.uk/news-opinion/sight-sound-magazine/interviews/memories-murderrithy-panh-missing-picture. Accessed May 22014.

O'Sullivan, Simon. "The Aesthetics of Affect.” Angelaki. Journal of the Theoretical Humanities, vol. 6, no. 3, 2001, 125-35.

Skoller, Jeffrey. Shadows, Specters, Shards. Minneapolis: University of Minnesota Press, 2005. Print.

Sobchack,Vivian. Carnal Thoughts. Berkeley: UC Press, 2004. Print.

Sontag, Susan. Regarding the Pain of Others. New York: Picador, 2003. Print.

The Missing Picture. Directed by Rithy Panh. Written by Rithy Panh and Cristophe Bataille. With Randal Douc and Jean-Baptiste Phou. 2013. 